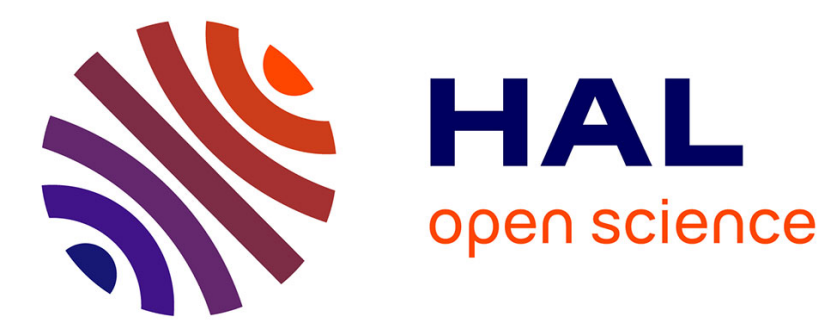

\title{
Mountain landscape, pastoral management and traditional practices in the Northern Pyrenees (France)
}

\author{
Jean-Paul Métailié
}

\section{To cite this version:}

Jean-Paul Métailié. Mountain landscape, pastoral management and traditional practices in the Northern Pyrenees (France). The conservation of cultural landscapes, pp.108-124, 2006. hal-01192738

\section{HAL Id: hal-01192738 \\ https://hal-univ-tlse2.archives-ouvertes.fr/hal-01192738}

Submitted on 3 Sep 2015

HAL is a multi-disciplinary open access archive for the deposit and dissemination of scientific research documents, whether they are published or not. The documents may come from teaching and research institutions in France or abroad, or from public or private research centers.
L'archive ouverte pluridisciplinaire HAL, est destinée au dépôt et à la diffusion de documents scientifiques de niveau recherche, publiés ou non, émanant des établissements d'enseignement et de recherche français ou étrangers, des laboratoires publics ou privés. 


\section{The Conservation of Cultural Landscapes}

Edited by - M. Agnoletti

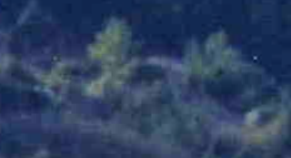




\title{
7 Mountain Landscape, Pastoral Management and Traditional Practices in the Northern Pyrenees (France)
}

\author{
J.-P. Métailié \\ GEODE - UMR 5602 CNRS, Maison de la Recherche, \\ Université Toulouse-le Mirail, Toulouse, France
}

\section{Introduction}

Mountain pastoral landscapes represent in all of southern Europe an immense heritage, shaped by successive phases since the Neolithic era. They are at the same time an economic resource, which is difficult to restore when it is degraded, a factor of biodiversity (as much botanical as faunistic), and also a cultural heritage. These landscapes were built and maintained for centuries or millennia by an agrosilvo pastoral system integrating all the functions of production and activation of the resources in the same places: agricultural production, pasture, litter and manure, gathering, charcoal, firewood, framework and craft industry. Today, in many regions, the crisis of livestock farming and land abandonment involve dramatic environmental changes, which are often very fast and threaten these landscapes. Spread of fallow land and afforestation are the main effects, but pastoral degradation includes phenomena of decline, in particular in heathlands.

The contemporary management of these extensive lands threatened by abandonment is involved today in a net of contradictions between, on the one hand, ideology of nature and conservation (some seeing the pastures as a pristine landscape), and on the other hand the willingness for management and economic development of the mountain. ${ }^{1}$ In the French Pyrenees as in other mountains, the agropastoral landscapes evolved during the last decades, but they are still relatively well preserved, especially in high mountain areas, because of the maintenance of livestock and recent reorganization of modes of exploitation (Eychenne-Niggel, 2003). The recovery of the agropastoral landscapes is today a local consensus, and the support for some traditional practices is recognized as one of the essential tools for this purpose. We will present here the past and contemporary role of two great 'groups of practices' (the management of the pastures by fire, and the management of the bocages and wooded pastures), and the prospects for their future use (Fig. 7.1).

\section{From the Historical Crisis to Precarious Revival: the Present Condition of Pastoralism in the French Pyrenees}

The disappearance of the practices and traditional knowledge is closely related to the economic and demographic crisis that the Pyrenees underwent more than a century 


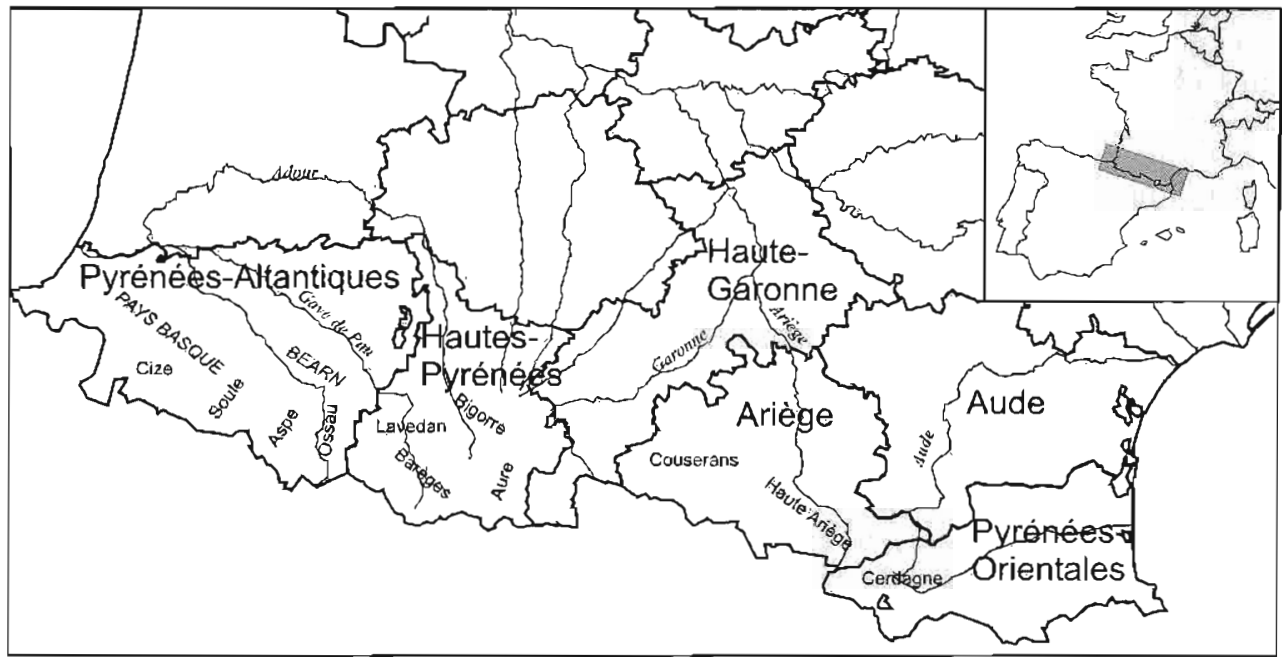

Fig. 7.1. Locality of the places discussed in the text.

ago. Rural emigration began in the 1830s in the eastern part of the chain (as in all the French Mediterranean mountains), but it only spread from the years 1880-1890, provoked by agricultural crises of the end of the 19th century. Until the 1930s, rural emigration mainly affected the poorest classes of the population: peasants without land, small artisans, and the workmen in metallurgical industries in decline. This emigration and the losses of World War I had paradoxically little consequence on the landscape dynamics because the main farms were maintained. Most of the great geographic and ethnographic investigations on the pastoral society were carried out during this time (Cavaillès, 1930; Lefebvre, 1933; Chevalier, 1952), and aerial photographs of 1942-1948 offer the vision of an agrosilvopastoral landscape still well maintained.

The great change occurred after World War $I$, in the context of economic growth and development of industrial agriculture between 1945 and 1975. During this period, $75 \%$ of the exploitations disappeared, involving a landscape upheaval without equivalent since the Middle Ages. However, tbis evolution was far from being uni- form, and each Pyrenean department, even each valley, presented specific characteristics. Depopulation, land abandonment and spread of fallow were more accentuated towards the east of the chain, and less dramatic and even unknown in the west. In Pyrénées-Orientales or Ariège there were many villages with only one farmer, and many others without any, whereas in Pays Basque there were still several tens of stockbreeders without estate, obliged to rent meadows on the plain in winter and mountain pastures in summer. The context of the maintenance of practices was thus very different according to the valleys and agropastoral systems.

From 1972 a new period started in France marked by the promulgation of the law on the 'pastoral development of the mountain', in particular creating Pastoral Land Associations (Associations Foncières pastorales) and Pastoral Groups (Groupement pastoraux), which were in the following decades the principal tools of the stock farming reorganization. The 'policy of the mountain' continued to develop at the end of 1970s, supported by the beginnings of the European policy of assistance for lessfavoured areas. In 1985, the new law for the 
development of the mountain led to an increased engagement of the local communities, even when the Common Agricultural Policy set up agro-environmental measures, which were very important for environment and land management. In the prolongation of these various policies the agencies of pastoral development were set up in each Pyrenean department. These dynamics lead today to a relative stabilization, even to a revival of farming, with maintenance of pastoral landscapes and with renewed attention to some traditional practices. Although the maintenance of mountain farming, essential for the management of the landscape, has consensus in France, that evolution remains fragile because of the repeated crises of the meat market (especially ovine) and of the uncertainty related to the perspectives of the Common Agricultural Policy. The number of pastoral exploitations continues to decrease regularly.

The last general census of agriculture (SUAIA Pyrénées, 2002) gives an overview of the current situation of the Pyrenees and evolutions foreseeable in the years to come (Table 7.1). It shows that the Pyrenees are divided today into three zones of pastoral economy:

- The eastern part (Aude, PyrénéesOrientales) where the agri-businesses are very few, but with rather young farmers and a high level of qualification. The greater landscape changes took place in the past, and dynamics of recovery are beginning. The productions are primarily of bovine and ovine meat. Traditional practices and knowledge can be con- sidered to have practically disappeared in these areas because of the strong decrease and renewal of the farming population, and consequent cultural change.

- The central part (Ariège, Haute-Garonne, Hautes-Pyrénées), with comparatively numerous agri-businesses but of the old, little-qualified farmers and a low number of young successors. Ovine and bovine herds for meat production largely use the collective pastures. Due to the ageing and progressive disappearance of the stockbreeders, there are clear prospects for abandonment and fallow land spreading in decades to come. Practices and knowledge are in the process of degradation and unequally maintained according to valleys.

- The western part (Pyrénées-Atlantiques) has the most intensive and dynamic farming, with a great number of businesses (half of the pastoral businesses of the whole mountain zone) and a high proportion of young and qualified farmers. Moor clearings and intensification have been carried out since the 1960s. Production is diversified, mainly based on sheep milk and cheese, but also on bovines for meat and milk. The good social and cultural continuity (especially in Basque Country) has allowed traditional practices and knowledge to be maintained.

What are the effects of these developments on the mountain pastoral landscape? Their dynamics are a complex phenomenon and difficult to evaluate at the Pyrenean scale, even for recent decades. The inventories

Table 7.1. The pastoral exploitations of the 'Massif zone' of the Pyrénées (SUAIA, 2002).

\begin{tabular}{lccc}
\hline $\begin{array}{l}\text { Departments } \\
\text { (from east to west) }\end{array}$ & $\begin{array}{c}\text { Number of pastoral } \\
\text { exploitations }\end{array}$ & $\begin{array}{c}\text { Number of cattle } \\
\text { units (UGB) }\end{array}$ & $\begin{array}{c}\text { Farmers } \\
\text { of more than 50 years }\end{array}$ \\
\hline Aude & $268(4.5 \%)$ & $12,069(4.3 \%)$ & $31 \%$ \\
Pyrénées-Orientales & $326(5.5 \%)$ & $16,995(6.1 \%)$ & $38 \%$ \\
Ariège & $924(15.4 \%)$ & $40,452(14.5 \%)$ & $42 \%$ \\
Haute-Garonne & $303(5 \%)$ & $10,384(3.7 \%)$ & $53 \%$ \\
Hautes-Pyrénées & $1449(24 \%)$ & $45,352(16.3 \%)$ & $50 \%$ \\
Pyrénées-Atlantiques & $2748(45.6 \%)$ & $153,243(55.1 \%)$ & $35 \%$ \\
\hline Total & 6018 & 278,495 & 2466 \\
\hline
\end{tabular}


available (land registers, forest inventories, general census of agriculture) use different typologies and methodologies for all that concerns 'moors', 'fallows' and 'waste lands', and cannot give reliable information on dynamics nor even real surface areas. To get more details, one can try an approach using two sources:

1. The National Forest Inventory (IFN), which was repeated at least three times with intervals of 10 years in all the Pyrenean departments since the end of the 1960 s with a uniform typology. ${ }^{2}$ It offers a negative of the pastures, by quantifying the growth of the woodlands in each 'forest area' defined by the inventory. In the Pyrenees, one can note that the growth of the surface area of woodlands reaches on average $1-2 \%$ per decade. In some areas at the edge of the central Pyrenees, which are very wet and where the forest has dominated the landscape for a long time, the growth reaches up to $5 \%$ реr decade. ${ }^{3}$ Tree colonization in the upper valleys is much slower; the only dynamics are perceptible in the moors and pastures, for which the inventory is not very reliable. ${ }^{4}$ In the western Pyrenees, the dynamics are still very weak, both in the upper valleys and the low mountains.

2. The systematic studies which began from the pastoral survey of 1999 , to inventory the pastures, and various research by scientific teams. These works give detailed information on the pastoral environment, but on the other hand the problem of contemporary and historical dynamics of the pastures remains very little investigated. In Ariège, a first assessment of spatial dynamics was made on 13 pastoral units; one could note that, according to the units, $20-50 \%$ of the surface of the mountain pastures suffered strong dynamics since the 1950s, either by spontaneous afforestation or by scrub colonization of the pastures. Numerous observations in the central and eastern Pyrenees (in particular by repeated photographs) (Métailié and Paegelow, 2004) confirm this dramatic evolution, which is rauch less pronounced or absent in the western Pyrenees.
In synthesis, one can say that the evolution of the pastoral landscape was dramatic in the Pyrénées-Orientales and Ariège, in particular in low and medium mountains (below $1600 \mathrm{~m}$ ); the high mountain pastures (above 1600-1700 m) are more stable, but do not escape either from important changes during the last decades. In the central Pyrenees (Haute-Garonne, HautesPyrénées\}, significant changes touched low and medium-sized mountains, while the high pastures remained rather stable until now because of the maintenance of a good pastoral pressure. In Béarn (Руге́néesAtlantiques), the good quality of the soil (many pastures are on limey ground) and a heavy pastoral pressure, related to the cheese economy, made it possible to preserve the pastoral landscapes until the 1980s; but a tendency for scrub and broom colonization has definitely been perceptible since 10 years ago. In the Basque mountains, on the contrary, stability seems the rule in the upper pastures, because of the maintenance of a very heavy pastoral pressure, both ovine and bovine (it is the only part of the Pyrenees where the ovine livestock increased because of the strength of the dairy economy). On the other hand, the hillsides of medium-sized mountains saw a contrasting development: new clearings and cultivations (meadows and maize) of the flatter areas, resulting in abandonment of the steep slopes. invaded by dense stands of bracken and Ulex.

\section{The Historical Role of Traditional Practices in the Construction of the Pyrenean Landscape}

\section{Fire, the main tool for construction and management of agro-pastoral landscapes}

Research in environmental history makes it possible today to highlight the multiform and generalized role of fire in the construction of the Ругеnean mountain landscapes (Fig. 7.2). The first evidence of clearings by fire in upper mountains is found in 
$500 \mathrm{~m}$

$1400-1600 \mathrm{~m}$

2000-2200 m

$2600 \mathrm{~m}$

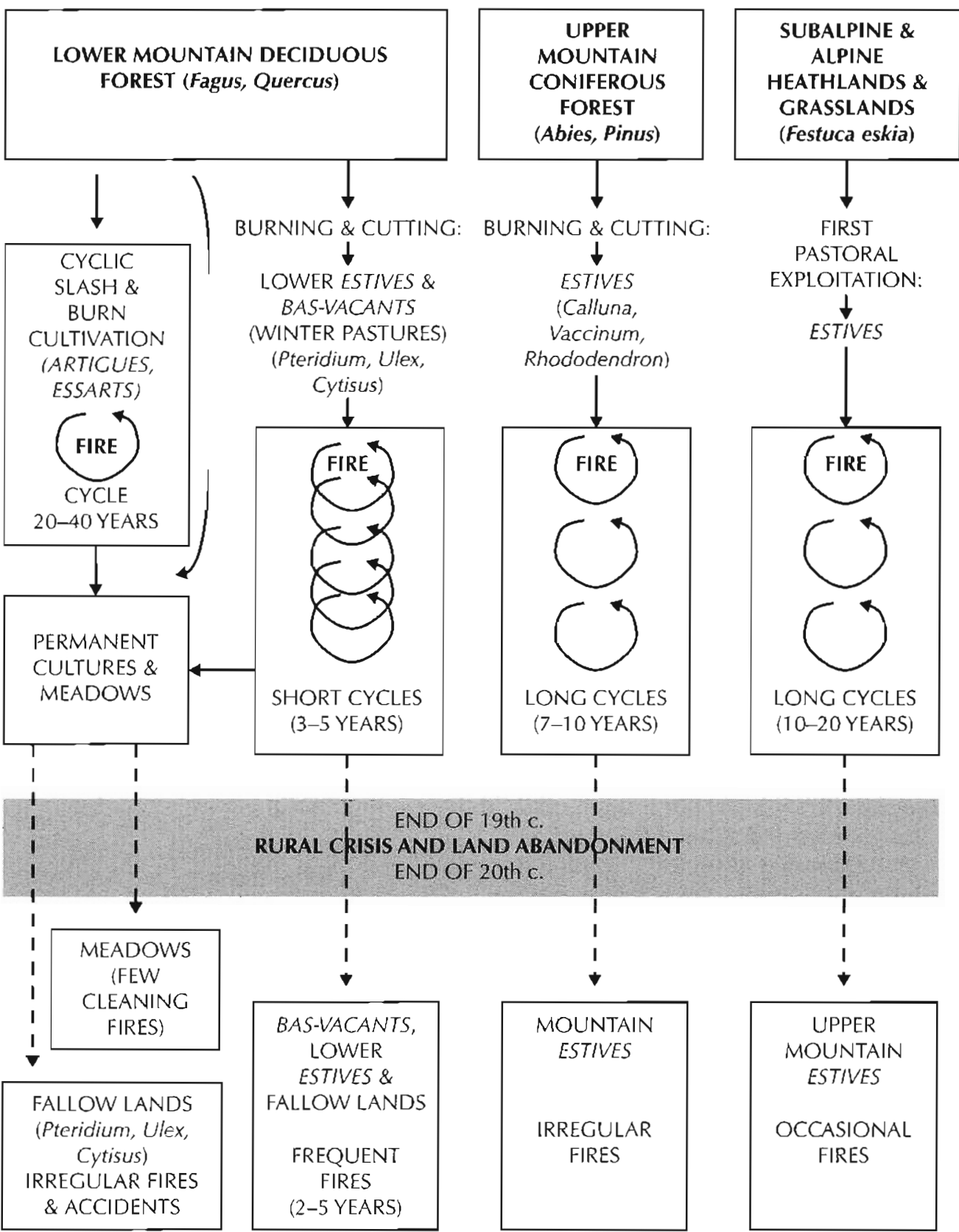

Fig. 7.2. Historical role of burning practices in the Pyrenean agro-pastoral landscapes. 
Catalonia (Cerdagne) as of the Neolithic era, towards $4000 \mathrm{BC}$ (Vannière et al., 2001); at the same time, slash and burn cultivations appear on the northern central piedmont (Galop et al., 2002). They intensify considerably towards the end of the Neolithic and the beginning of the Bronze Age, which represents the first great phase of creation of the pastures in all the Pyrenees. As at this time, several fire practices will coexist: the fire of pastoral clearing, by burning the edges or the whole woodlands; the running fire for maintenance of the pastures (which can easily lead to the clearing fire); slash and burn cultivation based upon a long cycle of coppice burning, every 15 to 30 years. It should be noted that maintenance by fire of silvo-pastoral forests, in particular the oak and beech stands of sunny slopes, had to start at that time. The impact of fire intensifies from the early Middle Ages up to the 14th century, a period of generalization of the agricultural and pastoral clearings, which will set up the Pyrenean soils. In the 14 th century, censuses of population show that practically all the current Pyrenean villages exist (a small number will disappear during the 15th century, while some others will appear during the 18th-19th centuries), with already important populations, equivalent to those of the middle of the 20th century. After the demographic crisis of the end of the Middle Ages, the last phase of construction of the soils corresponds to the 16th-18th centuries. Many overexploited forests disappear during this period; the pastures, systematically managed by fire, reach their greatest extent, and the woodlands evolve into coppices от grazing forests managed by current fires, except some bigh stands protected in the state or common forests (Métailié, 1996; Bonhôte et al., 2000).

The stabilization of the soils makes agricultural fire disappear gradually and the last clearings occur at the beginning of the 19 th century. ${ }^{5}$ After a long continuity of construction of the soils and generalized practice of fire, a short phase of stability succeeds, which remains today in the local memory as the apogee of the "traditional" landscape. Fire is then primarily a manage- ment tool of pastoral lands, well under control on account of the abundance of labour and the intensity of the agro-pastoral exploitation.

All this was over as from the 1950s: the acceleration of rural emigration, the abandonment of the land and the fast reduction in the herds cause a rapid spread of fallow lands which standardize landscapes, increase the combustible biomass and make the natural firebreaks disappear. The practice of fire then changes completely: aerial photographs and statistics show the change from frequent burnings on small surface areas distributed over the whole of the mountain, to fires at wide intervals, very vast and concentrated on the sunny slopes which are easiest to burn (Métailié, 1981; Faerber, 1996, 2000). In Ariège, for example, the average surface area burnt by fire increased between the 1940s and the 1980s from $5-8$ ha to 50 ha, while the number of fires fell by half. The reduction in the number of stock-breeders also resulted in a disappearance of the collective practices and knowledge, worsened by the social changes affecting the shepherds, with fewer and fewer coming from the local population.

Former practice was regular, "when necessary', and was made possible by a numerous labour force and a constant presence in the pastures; today fire is used 'when one can', according to the availability of the farmers and their friends. This evolution of the practice was paralleled by a major cultural change (Table 7.2); until the 18th century, one can consider that fire profited from a general social consensus: knowledge and standards were shared by all the mountain dwellers, and lords and peasants had the same culture.

From the 19th century, new standards and new scientific knowledge шете emerging, carried out by the engineers of the state administrations (Eaux et Forêts, Ponts et Chaussées) and by the first agronomists or phytogeographers. They are contradictory to those of the Pyrenean peasants and are opposed in particular to the traditional practices, like fire. This 
Table 7.2. Historical periods of fire practices and socio-cultural background.

\begin{tabular}{|c|c|c|c|c|}
\hline Time & Practices & Knowledge & Rules & Social actors \\
\hline $\begin{array}{l}\text { From Neolithic } \\
\text { to } 18 \text { th century }\end{array}$ & $\begin{array}{l}\text { Building of landscape: } \\
\text { slash and burn cultivation } \\
\text { (essarts, artigues), } \\
\text { clearing fire in forests, } \\
\text { pastoral fire in } \\
\text { pastures and moors }\end{array}$ & Vernacular & Local & Peasant society \\
\hline 19th century & $\begin{array}{l}\text { Stabilization of } \\
\text { landscape, } \\
\text { disappearance of } \\
\text { agricultural fire, } \\
\text { pastoral fire exclusive }\end{array}$ & $\begin{array}{l}\text { Opposition between } \\
\text { local knowledge } \\
\text { and scientific } \\
\text { knowledge }\end{array}$ & $\begin{array}{l}\text { Local rules vs. } \\
\text { national rules }\end{array}$ & $\begin{array}{l}\text { State engineers and } \\
\text { administrations }\end{array}$ \\
\hline 20th century & $\begin{array}{l}\text { Agro-pastoral crisis } \\
\text { Fallow lands spreading } \\
\text { Degradation of } \\
\text { common fire practices }\end{array}$ & $\begin{array}{l}\text { Crisis of local } \\
\text { knowledge, increasing } \\
\text { power of technical } \\
\text { and scientific knowledge }\end{array}$ & $\begin{array}{l}\text { National and } \\
\text { European }\end{array}$ & Multiple protagonists \\
\hline 21 st century & $\begin{array}{l}\text { Use of fire for global } \\
\text { land management } \\
\text { Potential difficulties due to } \\
\text { changes in local society, } \\
\text { climate and vegetation } \\
\text { changes? }\end{array}$ & $\begin{array}{l}\text { Adaptation of local } \\
\text { knowledge? } \\
\text { Generalization of } \\
\text { prescribed burning? }\end{array}$ & European? & $\begin{array}{l}\text { Multiple protagonists } \\
\text { on European scale? }\end{array}$ \\
\hline
\end{tabular}

situation evolves quickly to a prohibition, in fact, of the burning practices (although burning remains legal and simply regulated), which will bring the stockbreeders to clandestine practices and uncontrolled fire. This tendency to prohibition and conflict is accentuated during the 20th century, in a context of disintegration of the mountain society, increasing power of the administration and multiplication of the social or institutional groups intervening in mountains. The practice of fire is bound more and more to national or European standards, in spite of the scientific rehabilitation in progress since the 1980s. It is clear that there is an evolution towards an increased technical and legal framing of the practice, in spite of the efforts of the agents of development to manage it at the local level, on the basis of adapted traditional knowledge. One cannot exclude either a return to strong regulations or prohibition.

\section{The peasant forest: bocage and wood pastures, a pastoral design of the forests}

The use of the forest as an essential element of the agro-pastoral system probably began at the same time as pastoralism (Sigaut, 1987). The leaves of many trees provide good fodder and are convenient to use: before the scythe, cutting branches was easier than mowing grass, storage was possible without barns, and many trees have persistent foliage by winter. The beechmasts and oak acorns are also very important resources, mainly for pigs but also for sheep (even for man). Recent archaeopastoral research shows that the farming and transhumance of pigs in the oak and beech forests were already widespread in the Bronze Age in the Basque mountains (massif of Irati and Arbailles, for example ${ }^{6}$ ); this tradition remained until the 19 th century, as in many other Pyrenean valleys (Bigorre, Aure). 
Fraxinus excelsior is the best known forage tree, but the list of the taxa used in the Pyrenees is very long: Populus nigra, ${ }^{8}$ $P$. italica, ${ }^{9}$ Quercus petraea, Q. pyrenaica, Q. pedunculata, ${ }^{10}$ Q. ilex (for goats), Prunus avium, Tilia cordata, Alnus glutinosa, Salix, Acer; Abies alba was also bred for bovines and sheep, ${ }^{11}$ like Fagus sylvatica. ${ }^{12}$ It is necessary. of course, to add Castanea sativa, which was not a fodder tree, but whose plantations constituted important grazing forests on lower slopes. Many types of foliage are used only after drying, because they are considered too 'strong' in a green state for the animals (Populus, Fraxinus). There is, unfortunately, little historical documentation on these practices during the centuries when they were most widespread (the 17th to 19th century), when stock farming was under the permanent threat of the winter forage shortage, because of the extreme extension of the cultivations to the detriment of the meadows. Mention appears only indirectly in the archives, when shortage crises led the stock-breeders to make requests for cutting branches in the forests ruled by the Forest Administration. ${ }^{13}$ Foresters and agronomists regarded them as aberrations, caused by the insufficiency of the meadows, and did not give any attention to them; only some authors gave an account of it. First is Louis de Froidour, Réformateur and Grand Maître des forêts in 1667, who visited all the Pyrenees and, parallel to his administrative and legal action, noted the agricultural as well as pastoral uses. Thus, he describes the pollard forests of the Basque Country, 'true orchards of oaks', used for intensive breeding of pigs; generally, he protests against the practice of pruning which he considers too frequent, without care and leading to the exhaustion of the trees. At the end of the 19th century, in 1889, Henri de Lapparent, agronomist and inspector of agriculture, made a study trip to the Pyrenean pastures; being at variance with the opinions of this time, he justified the pastoral use of the forest and recommended even the transformation of the less productive stands into 'fodder coppices' (Lapparent, 1890). One can find a similar analysis in the works of Felix Briot on the pastoral economy of the Alps (Briot, 1907); ${ }^{14}$ he describes many silvopastoral woodlands like fodder coppices of beech or alders, or pruned fir mixed with coppices, and analyses their profitability.

The country forests had many other well-known uses, like firewood, and the production of charcoal, tools, wooden shoes and frame timber. The demographic growth and the intensity of the exploitation during the 17th-19th centuries led to the disappearance of many forests, especially in the areas with strong metallurgical activity (Ariège and Catalonia). In the valleys with predominating agropastoral economy (Bigorre, Béarn), the destruction was of less importance but the forest landscapes were deeply transformed: generalization of coppices, of sparse forests with herbaceous undergrowth and of pollard trees. ${ }^{15}$ The practices of maintenance of sylvo-pastoral woodlands disappeared during the 20th century, but much of the grazed forests last to this day because of the maintenance of a heavy pastoral pressure and use of fire: in the Hautes-Pyrénées, the Forest Inventory individualizes a category 'sparse forests', which accounts for $8.8 \%$ of total forest area. ${ }^{16}$ Many wood pastures are still managed by fire (Fig. 7.3). In the Basque Country, the wood pastures and oak-pollard landscapes are still very widespread in all the hills and lower mountains (but pollarding is no longer practised).

Probably a long time after the construction of the agrosilvopastoral forests, a second type of peasant forest was created: the Pyrenean bocage. Its forms are rather different from those of western France: it is discontinuous and limited to soils with irrigated meadows; barns are very numerous, up to one per plot. Generally low fences $(1-1.20 \mathrm{~m})$ prevent the passage of the animals, sometimes stone-built but mainly vegetal (Corylus, Buxus, Cratægus, Prunus, Cornus), associated with fodder trees. The branches of hazel are cut every year in winter and are used for basketmaking and firewood. Ashes surmount the hazel fence at intervals of a few metres, formerly pruned every 4-5 years in 


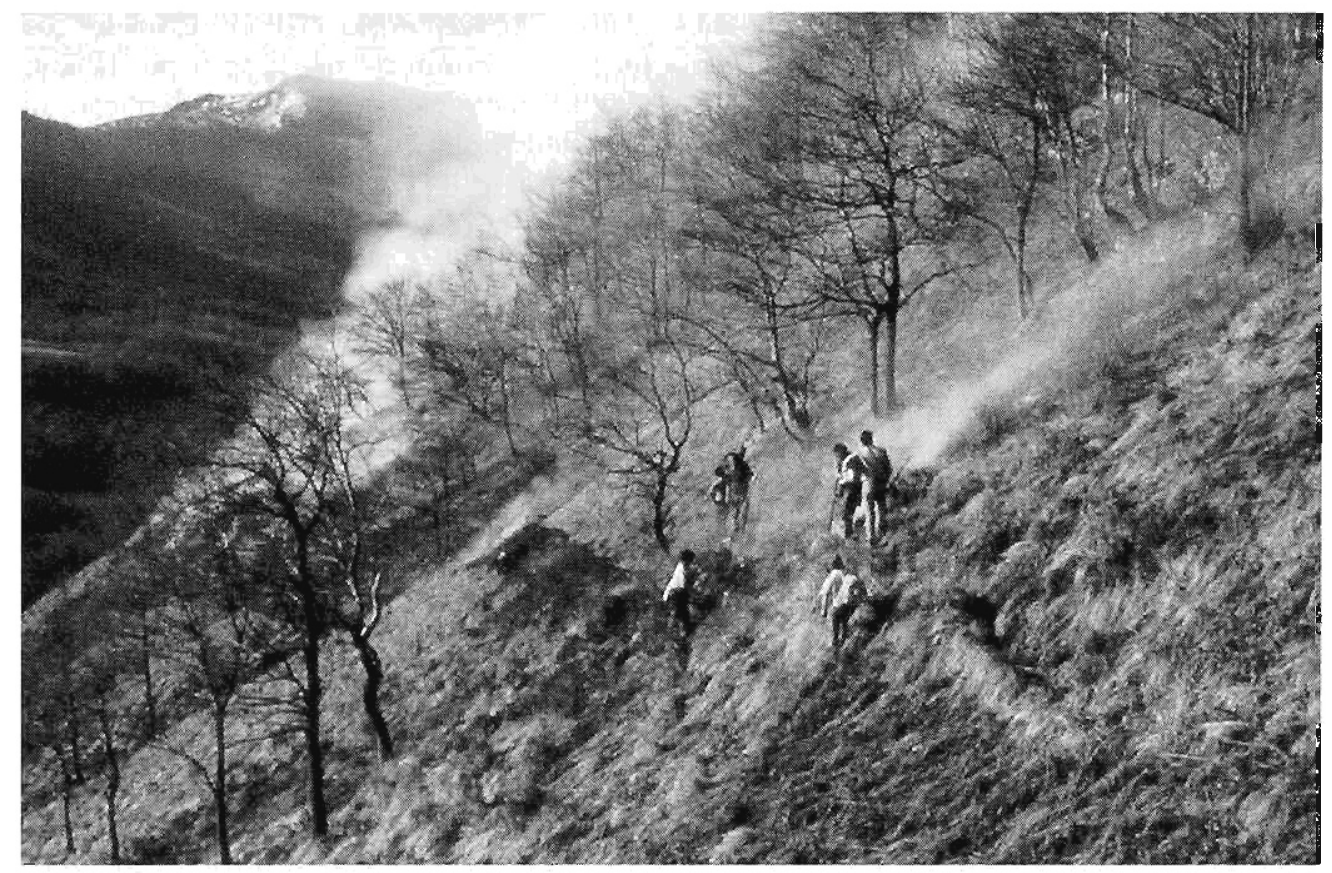

Fig. 7.3. Winter burning of bracken and Brachypodium in a pastoral oakland, Lavedan (Hautes-Pyrénées), 1994. (J.P. Métailé).

August-September, but many sources relate the collection of the leaves every year. In general, people brought together branches and foliage to make faggots and stored them in the barns or in the plots; sometimes it was even stored in the tree, beyond the reach of the cattle (in Occitan: la fullera, Fig. 7.4) and given to the animals throughout January and February. The large branches of ash were used to make firewood, fences, plates and tools (cattle collars, rakes, forks, etc.). In the cultivated soil (cereals, potaloes, etc.) the obligation of common grazing prevented the construction of fences to allow free grazing after harvesting. The meadows were, on the other hand, for private use, and it was important to protect them from the bordering herds from spring onwards and to maintain their owners' own cattle in winter. ${ }^{17}$

The chronology of the construction of the Pyrenean bocage is not clear, and its origin, like all the other bocages, is difficult to know. Anthracological studies on the Gallo-Roman forges of Riverenert (Couserans, Ariège) showed that, during the 1st century $\mathrm{AD}$, charcoal was made using taxa such as Corylus, Prunus, Acer and Juglans. This does not prove the existence of a bocage, but reveals a landscape with hedges and sparse woods. Fraxinus, which is the present key element, is present in the Рyrenean pollen diagrams as early as the Neolithic period (Galop et al., 2002), but the real importance of ash in the landscape is difficult to reconstruct, because of the pruning, which prevents flowering and pollination. In the 17th century, some forest maps of the Reformation reveal a net of hedges and fences ${ }^{18}$ and at the end of the 18th century there are dendrochronological evidences of ash hedges in the Spanish Pyrénées (Gomez and Fillat, 1984). The most credible hypothesis is that the construction of bocage was probably parallel with the creation and private appropriation of the irrigated meadows during the Middle Ages and modern times, and with the rarefaction of forest resources. This evolution is highlighted in Champsaur (Southern Alps) (Court-Picon, 2003): the beginning of the ash bocage is noted during the Middle 


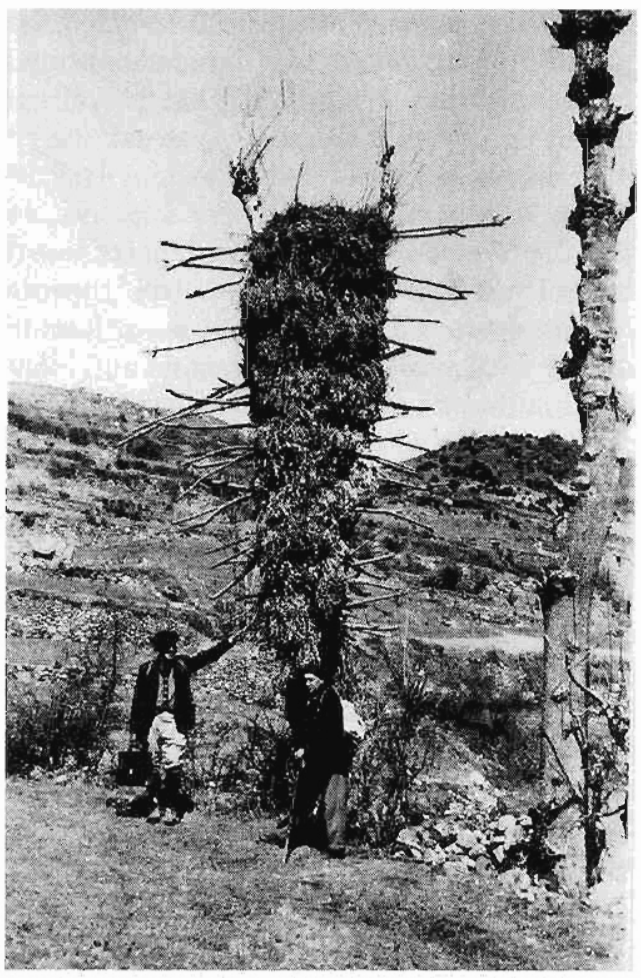

Fig. 7.4. 'La fullera': leaves of Fraxinus excelsior stored in the tree after pruning (Ariège, 1952). (coll. Office National des Forêts).

Ages, and the greatest development takes place during the 17th and 18th centuries. The latest increase of ash pollens in the diagrams corresponds to the cessation of pruning and the growth of trees during the 20th century. This type of evolution can be seen in present tinaes in Nepal, where recent deforestation and forest regulations have limited access to woodlands and induced the plantation of hedges for leaf fodder and firewood (Bruslé et al., 1997); in this subtropical environment, 56 taxa are used.

\section{Between Heritage and Development: the Precarious Survival of Traditional Practices in the Pyrenees}

\section{From peasant fire to prescribed burning}

The question of the management of pastoral fires in the Pyrenees showed a complete inversion during the last 15 years. For a long time, fire was blamed for the degradation of pastures and forests; the agents of the administration and the foresters tried to remove this 'archaic' practice, or at least to regulate it strictly. However, according to the scientific research of the last 20 years, which highlighted the logic and the role of pastoral fire, it is now recognized as a tool and not a constraint or a threat. The rehabilitation even reached a point that was unbelievable 20 years ago: prescribed burning was officially included in the forest law of 9 July 2001 as a technique for the prevention of forest fures.

\section{The logic of the practice}

In the Pyrenees, the majority of the pastures are made up of heathland, fern, broom and gorses, on poor and acid substrates, unfavourable for herbaceous vegetation. To have a fodder resource, the stock-breeders need periodic fire, bunning scrub and dry biomass and regenerating (cleaning) the grassland. The idea of cleanliness is closely related to the image of fire in the mountain society: when the mountain is dirty, you have to clean it by fire (Ribet, 1996); grass is clean and scrub is dirty. This cultural logic of fire is based on a precise knowledge of the dynamics of the vegetation and its rhythms: running fires are practised during the period of rest for the plants - in the autumn or at the beginning of spring; the duration of cycles is linked to the speed of growth and to pastoral pressure. The planning and technical management of burning is based on an intimate knowledge of the mountain, of local climate and slope microclimates, of fire behaviour in general and in precise places. In each village there were skilled men, 'fire leaders' who organized the burning when it could be carried out officially or, in contrary cases, did it clandestinely (Métailié, 1981, 1998; Faerber, 2000).

\section{Contemporary decline of the practice and knowledge}

Over the last 50 years, the consequences of rural emigration and pastoral abandonment 
have resulted in a major change in the nature of Pyrenean fire: the pastures are fallowing, in particular on the lower slopes close to the villages, the combustible biomass increases, the former limits and landmarks are disappearing. We can say that the territory escapes to the stock-breeders, and by consequence fire itself: it no longer has the same behaviour, no longer stops at the usual places and spreads unusually far. The multiplication of afforestations, of equipment (power lines, telephones, etc.) and of tourists' homes constitute increasing fire risks.

In parallel, the mountain society changed: the number of stock-breeders unceasingly decreases, which makes the collective control of burning more difficult, even improbable. The know-how disappears at the same time as the old fire leaders, or it does not evolve and becomes unsuited to the new environment. Lastly, the power of the administration and other social groups increases: foresters, of course, but also firemen, hunters, agricultural agencies, police, ecological associations, tourists and 'neo-rural' residents, etc. They constitute special interest groups and it becomes difficult for stock-breeders to maintain a less and less controlled practice, causing increasing damage; they are becoming a minority in the country and they have to take that into account. ${ }^{19}$

The development of the local practices takes, today, approximately three forms in the Pyrenees. In some valleys, mainly in the west, in Basque Country, the stock-breeders are in great number, the pastoral pressure is heavy, and the traditional practices are maintained, which allows a local, traditional management of burning, which is relatively well controlled. In other valleys, the absence of the control of pastures and fallows is accompanied by dangerous individual practices, heirs of a long history of conflicts and clandestineness. This is the case, for example, in some valleys of Ariège, where individual stock-breeders and pensioners are desperately burning to clean the mountain' in abandoned zones, without concern for the consequences. In the majority of other cases, the stock- breeders who need the fire to manage the pastures are receptive to a transformation of its organization. It is in this general context that the experiments of management of burning have developed over the last 10 years, in all the Pyrenean departments, in the form of technical groups or of local committees. They represent a true rupture in the history of the practice, a test to modify at the same time the social and technical patterns.

\section{From burning to land management}

The forms of dialogue and management of burning are different according to departmental contexts in the chain, and are mainly of two types: on the one hand, dialogue and realization of burning by a professional team; on the other hand dialogue and organization of fires by the local people. The key word remains always that of dialogue, a departure from the preceding repressive attitudes of administrations (Métailié and Faerber, 2003).

In the Pyrénées-Orientales, the local pastoral agency set up a specialized team in 1987, in order to deal with burnings necessary for stock-breeders (Lambert and Parmain, 1990). It was considered that the level of risk was too high in the Mediterranean environment, and local technical capabilities too limited, to leave the management of fires to the stock-breeders alone. Неге the traditional practice was banished. The team, made up of pastoralists and foresters, collects the requests for burning, discusses them with the local partners, prepares burnings and carries them out, in collaboration with units of firemen. This organization took advantage of the Mediterranean context and the policy of forest-fire prevention. Such fire management is today developing in all the French Mediterranean zone where, according to departments, foresters or firemen organize burning campaigns, either with a pastoral objective or for prevention of forest fires (PASTUM, 1998).

In the remainder of the Pyrenees, to take technical responsibility for all the burnings would be unrealistic: on the one 
hand, the stock-breeders are still numerous and would not agree to be excluded from the management of their lands; on the other hand, the very great number of fires necessary each year in the various valleys would make impossible their realization by a professional team. In the Hautes-Pyrénées, since 1989, the choice was that of local committees (at the level of the canton or the valley), allowing first the dialogue between all the partners. In these committees, the various local protagonists present their points of view and discuss the benefits or risks of burnings, setting up zones of land and fire zones. One of the essential actions of the committees remains provision of local information on regulation and techniques. The objective is the end of clandestine burnings and the revitalization of collective fire practices, using traditional knowledge and modern tools (drip torch, water, fire-beater). Accordingly, fire must become again an agricultural tool like any other. The progressive installation of the committees in the mountain cantons allows a slow but relatively sure diffusion of this new collective management of fire.

In Ariège, a burning committee was set up at the level of the whole department. Parallel to the usual work of dialogue and information, the committee led to the constitution of a semi-professional burning team, made up of shepherds. The team was created based on the evidence that, in many cases, the local protagonists needed help because they were not numerous enough or no longer had the know-how to control their burnings. After 2 years, the team had to stop, through lack of funds, and the firemen took over the programme again; but, unfortunately, they do not have appropriate relations with stock-breeders. At the present time, the problem of fire management and evolution of practices has still not been worked out. On the one hand, the stockbreeders organized within Pastoral Land Associations or Pastoral Groupings generally changed their practices by integrating fire in the current and lawful management. However, on the other hand, the clandestine practices were not controlled and continue to cause important scrub and forest fires.
The Pyrénées-Atlantiques represents a particular problem because the department includes as many stock-breeders as the remainder of the Pyrenees. That has two important consequences. First, the number of farmers in only one commune can be equivalent to that of a whole valley in another department; the problems of dialogue and the potential conflicts are thus multiplied. Secondly, the requests for burnings have also multiplied - in some communes the mayors receive 60 to 80 declarations of burning per annum, which is equivalent to several cantons in the neighbouring departments. Furthermore, traditional practices are still very much alive, and the farmers are not generally disposed to accepting criticism.

A first attempt at installation of a burning committee was made in 1989, in the valley of Soule (Basque Country), based on a similar model to the cantonal committee of the Hautes-Pyrénées. However, the experiment failed because of the lack of funds and continuity in the animation of the committee, but also of contradictions between the 43 communes of a very large and populated valley. The committee also encountered a strong inertia of the local farmers, who think they have nothing to learn about fire from technicians. Other actions were then started in Béarn in 1994-1995 (Aspe valley), where a local request for management of fires was better expressed. After 2 years, the first assessment highlighted good participation of shepherds and stock-breeders, and of the mayors, a change in the practices and good control of burnings. The second time, this commission profited from a local agro-environmental measure ('Patrimonial management of pastoral landscapes and protection of the bear in the valleys of Béarn') including the management of natural risk, within which prescribed burning was financed (1998-2002).

In spite of that, no dialogue was really developed at the departmental level during all these years. It will be started again only after the shock of the dramatic accidents in 2000 and 2002. On 10 February, 2000, eight bikers on the GR10 trail were trapped by a 
fire in the valley of Estérençuby in Basque Country - five of them died and two others were seriously wounded. The site of burning was perfectly banal for the Basque mountains: a steep slope with dense grassland of Brachypodium pinnatum, frequently burned, where the fire reached a mortal velocity for tourists without knowledge of fire behaviour. It should be noted that the stock-breeders regard themselves as the only inhabitants of the mountains (especially in winter) and burnings are usually started without any specific precaution or information; the stock-breeders of Estérençuby are indifferent to the welfare of passing tourists. The gravity of the accident and the questioning of the practices which underlay it caused a shock in the department, restarting the discussions on the management of burnings and the creation of a departmental committee.

In this context another catastrophe occurred in February 2002. After several weeks of winter dryness and snow melting, there was a spell of strong, hot southerly wind over the whole of the Pyrenees. On 3 February 2002 the maximum temperature in the lower valleys reached $28^{\circ} \mathrm{C}$, while on the high slopes the winds reached $80-100$ $\mathrm{km} / \mathrm{h}$. Logically, no burnings should have been carried out under these conditions any control is impossible with winds exceeding $20-30 \mathrm{~km} / \mathrm{h}$, and the extreme dryness of the vegetation meant that the moisture which normally stops the fires in the thalwegs or on the northern slopes was absent. In spite of that, many stock-breeders started burnings in situations where they were difficult or impossible to control. In the Pyrénées-Atlantiques, especially in Basque Country, usually the wettest area of the chain, the damage was the most severe: more than 5000 ha of forests were burned, in sectors never touched before (high beech stands of northern slopes). The impact on the forests was thus considerable, even if in the majority of the cases the fire was an under-wood fire; burned woodlands lose any commercial value, and the losses were estimated at 1.8 million euros. An old farmer was trapped by a fire and died. The gravity of the consequences again re-ignited the debate in favour of departmental input and the creation of local committees in 2001-2003, under the care of the Association of Mountain Mayors and of the Chamber of Agriculture.

The principal effect of these repeated serious accidents was to highlight the deficiencies of traditional burning practices in Basque Country. Paradoxically, the risks are increasing in a context of intensive pastoralism, which is confronted to changing a social and biological environment. For the years to come, the challenge of the committees is to convince the stock-breeders to adapt their practices and organize burnings better.

The rehabilitation of fire during the last 20 years was particularly spectacular in the Mediterranean area, where it led to the integration of prescribed burning into fire prevention as a clearance technique associated with stock-breeding. From 1989, the creation of the Prescribed Burning Network, an association of agronomists, firemen, foresters and pastoral agents, led to a technical framework of burning which made it acceptable for the forest services (PASTUM, 1998). The Forest Law of 9 July 2001 confirmed this development by recognizing the prescribed burning as a technique for fire prevention. However, this 'cultural revolution' at the level of the Forest Administration does not resolve the problem of the traditional fire. The 'prescribed burning' is becoming an administrative standard, with legal codification corresponding to a very technical organization with the objective of forest-fire prevention. These constraining rules are suitable for the burning teams of the Mediterranean area, made up of foresters and firemen who are heavily equipped, and who carry out a small number of burnings every year in high-risk zones and use the technical model of American prescribed burning. Unfortunately, it is impossible to apply this model to the practice of the shepherds and stock-breeders in the Pyrenees. Hundreds or thousands of burnings are made every year, and in this case the main objective is responsibility, observance of the legal rules and good technical management of the fire. 
There is thus a risk of the practice of fire again being limited by new technical standards, even prosecutions if new serious accidents happen. Now the conditions for such accidents are becoming more frequent, especially if the current climatic evolution causes more frequent winter dryness. The practice of pastoral burning thus arrives at a historic turning-point, similar to the disappearance of the agricultural uses of fire 200 years ago. The change of the second half of the 20th century seems irredeemable and will oblige the stock-breeders and shepherds to adapt their ancestral practice and integrate new technical and social arrangements. The pastoral logic of fire must be integrated today in a global mountain land-management policy.

\section{The precarious future of the bocage}

What is the current evolution of bocage management in the French Pyrenees? The pruning of the ashes continues in some valleys (Ariège, in some communes of Couserans; Hautes-Pyrénées, in Lavedan, valley of Barèges; Pyrénées-Atlantiques, in the valleys of Aspe, Ossau, Soule and Cize), where the collection of leaf fodder is relict. In most of the valleys, it is extinct, except during droughts, and pruning is practised mainly for the firewood ${ }^{20}$ and a few crafts. The chronology of disappearance of the practices is clearly shown by photographs and ethnographic investigation: during the years 1950-1960, the bocage was still busily used and the landscape well maintained in all the valleys. The decline began during the 1970s, but at the time of the drought of 1976, the ashes were pruned again for forage in all the Pyrenean valleys, even where the practice was already extinct. At the time of the drought of 2003, in spite of a great forage shortage, the farmers preferred to buy costly hay, and the ashes were pruned only in the few valleys where the practice is still alive. In some places, farmers simply cut whole trees into the meadows to allow breeding. The change of working conditions (increase in the size of the farms and of the herds, lack of time) and the increased integration of intensive agriculture explain this disaffection. ${ }^{21}$

The decline of the practice of pruning occurred especially in the 1980s, but recovery attempts took place as of the 1990s. At that time, management and restoration of rural landscapes became stakes for the local elect and the agencies of development. They were based on a succession of procedures and financings, national or European: European agro-environmental measures, from 1985, to maintain practices compatible with good environmental management (pasture and mowing, but also burning in some cases); the 'Grass Grant' in 1993; Rural Areas Management Funds in 1995; and Territorial Exploitation Contracts in 1998, replaced in 2002 by the Sustainable Agriculture Contracts. ${ }^{22}$ The conservation of the bocage remains one of the principal objectives in the majority of the projects. Generally, these measures are used to compensate for the lack of local labour by financing the realization of work by specialized companies. This is what occurred in the hamlet of Laspe, in the commune of Sentein (Couserans, Ariège) - until about 1990-1995, the bocage was still particularly well managed and all its uses maintained by two families, especially the old people. This landscape was considered as an important heritage in a valley where fallows were quickly spreading. From 1995, a programme of fence building, maintenance of the byways and ash pruning was undertaken by local pastoral groups, and mainly carried out by one stock-breeder, helped by a company (Fig. 7.5). The principal problem on this level remains to obtain regular financing to care for the bocage at least every $4-5$ years.

\section{Conclusion}

The traditional practices in the Pyrénées are today in a paradoxical situation. For the majority they are clearly disappearing, but they are also perceived as a cultural heritage indispensable for the maintenance of the landscape of pastures, bocage and terraces. In the case of the bocage, the 


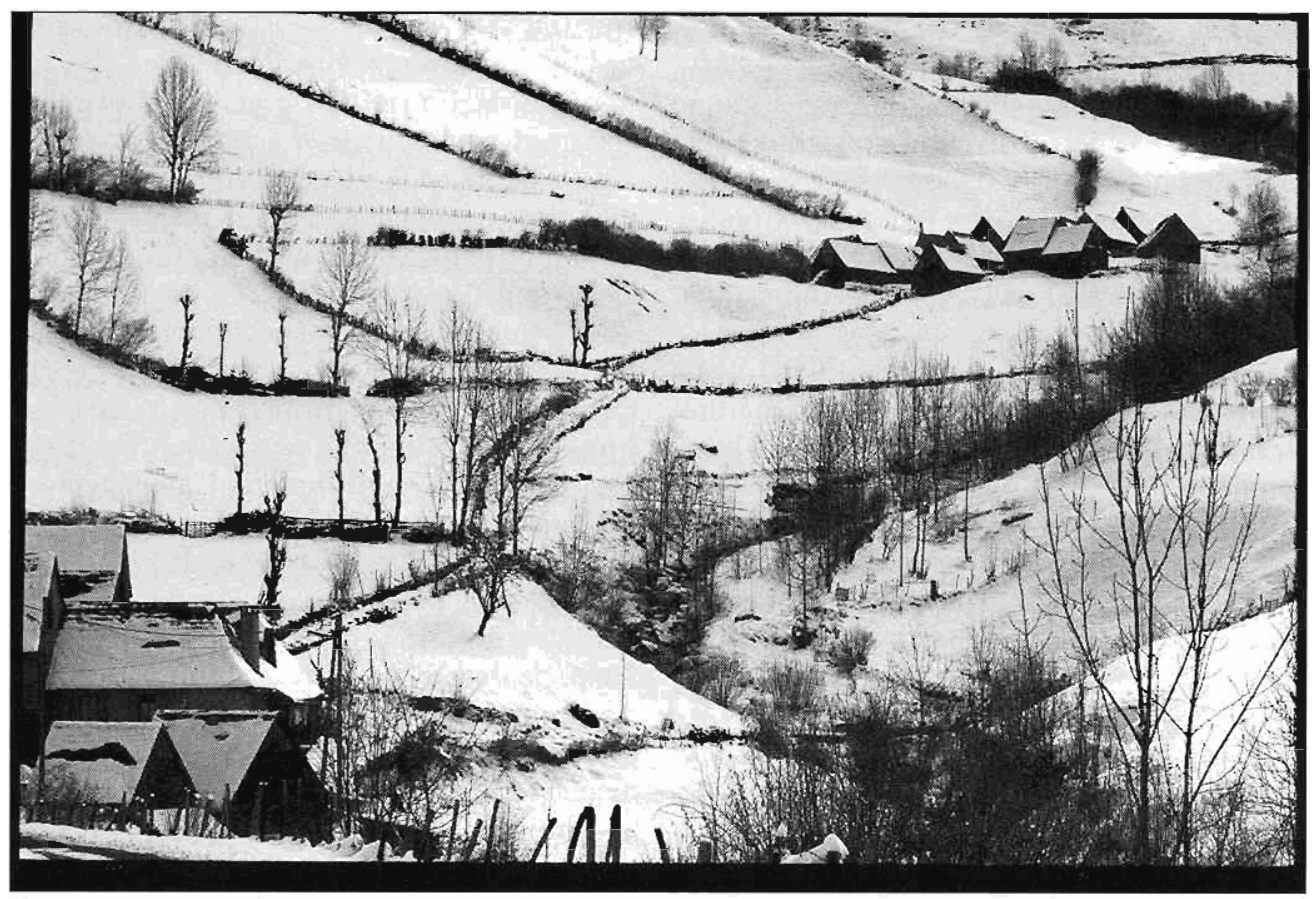

Fig. 7.5. Landscape of Pyrenean bocage in winter: hamlet and barns of Laspe, in the Biros valley (Ariège), 2002. (J.P. Métailié).

practices are disappearing, but the social consensus on the landscape moves towards an assumption of management by the local communities, in forms related to agro-environmental policies. In the case of fire, it is the reverse: the practice is considered as 'too alive' by certain people, its social acceptance is not guaranteed and it is necessary to adapt the burning to a new social and biological environment.

\section{Notes}

1. The current conflict over the reintroduction of large predators (bear and wolf) characterizes this opposition between the perceptions of the mountain; even the Natura 2000 project is a case of conflict, because the local elect perceive it as a loss of control of the territory.

2. National Forest Inventory (see wuw.ifn.fr). Ariège: 1968, 1978, 1990; Hautes-Pyrénées: 1974, 1986, 1997; Haute-Garonne: 1972, 1987, 2000; Pyrénées-Atlantiques: 1971, 1984, 1995.

3. For example, in the Couserans (Ariège) forests increased between 1978 and 1990 from 36,290 ha to 40,597 ha. On the northern edge of Hautes-Pyrénées, between 1986 and 1997, forests increased from 53,502 ha to 55,314 ha.

4. The typology of woodlands is homogeneous from one inventory to another, but this is not the case for moors, pastures, wastelands, etc., and such data are not useful for our purpose.

5. There is evidence of clearings at the beginning of the 20th century in forest archives and ancient photographs, but they are relict practices.

6. Collective research project 'Palaeo-environment and anthropisation dynamics in Basque mountain', 2000-2003, coordinated by D. Galop.

7. At the end of the 19th century, in the valley of Bareilles (Aure), herds of pigs were assembled for breeding in the oak lands of the state forest (Métailié, 1986). 
8. The bocage with P. nigra still exists in Cerdagne and the Spanish valleys, but is not maintained.

9. Populus italica was the last bocage tree to arrive in the Pyrenees. Coming from central Asia, the first clones were imported by the Royal Garden at the end of the 18 th century. Its success was very quick, because of its multiples uses, and it was one of the major elements of the Pyrenean landscape during the 19 th century. The poplar bocage declined in France after the 1950s, but it is still rather important in the Spanish Pyrenees.

10. These three taxa make up the Basque pollard landscape.

11. Young firs still constitute an under-wood pasture for bovines.

12. The beech seedlings are bred during the spring. In the Ligurian Apennines, pollard beeches were used for fodder until the 1950s (Moreno and Poggi, 1998).

13. Archives and other sources are numerous in Italy and the comparison can help us (Moreno and Poggi, 1996, 1998).

14. Briot, an atypical 'pastoralist forester', was one of the founder members of the Society of Alpine Economy (1913), which has evolved into the current French Federation of Mountain Economy.

15. This woodland type, much extended throughout all of southern Europe (see the dehesa and montado) was conceptualized as 'savannas' by Rackham (1996).

16. IFN, Hautes-Pyrénées, 1996.

17. In some valleys, common grazing was practised in the private meadows from October to March (Chevalier, 1952).

18. Bethmale Valley: Arch. Départ. Haute-Garonne, série B, Réformation de Comminges, 0-3 (1668).

19. Some mayors of mountain communes, who are townsmen in the countryside, simply forbade the burnings.

20. It is interesting to note that the bocage exploitation produces two-thirds of the firewood of the Midi-Pyrenees region.

21. The ash fodder is still well used in the Spanish valleys and it is possible to find some practices, like the 'fullera', which have disappeared in France.

22. In French: Prime à l'herbe, Fonds de Gestion de l'Espace Rural, Contrat Territorial d'Exploitation, Contrat d'Agriculture Durable.

\section{References}

Bonhôte, J., Davasse, B., Dubois, C., Galop, D., Izard, V. and Métailié, J.P. (2000) Histoire de l'Environnement et cartographie du temps dans la moitié est des Pyrénées: pour une "chrono-chorologie". In: BarruéPastor, M. and Bertrand, G. (eds) Les Temps de l'Environnement. Presses Universitaires du Mirail, Toulouse, pp. 501-515.

Briot, F. (1907) Nouvelles Études sur l'Économie Alpestre. Berger-Levrault, Paris.

Bruslé, T., Fort, M. and Smadja, J. (1997) Un paysage de bocage. Masyam et le hameau de Kolang. In: Smadja, J. (ed.) Histoire et Devenir des Paysages en Himalaya. Paris, CNRS Editions, pp. 485-527.

Cavaillès, H. (1930) La Vie Pastorale et Agricole dans les Pyrénées des Gaves, de l'Adour et des Nestes. Colin, Paris.

Chevalier, M. (1952) La Vie Humaine dans les Pyrénées Ariégeoises. Génin, Paris.

Court-Picon, M. (2003) Approche palynologique et dendrochronologique de la mise en place du paysage dans le Champsaur (Hautes-Alpes, France) à l'interface des dynamiques naturelles et des dynamiques sociales. Thématique, méthodologie et premiers résultats. Archéologie du Midi Médiéval 21, 211-224.

Eychenne-Niggel, C. (2003) Trente ans de relance pastorale pastorale en Ariège: le temps de la maturité. Les enseignements de l'enquête pastorale de 1999 et du recensement agricole de 2000. Sud-Ouest Européen $16,5-14$.

Faerber, J. (1996) Gestion par le feu et impact sur la diversité : le cas des friches sur les anciennes terrasses de culture dans les Pyrénées centrales. JATBA (Journal d'Agriculture Topicale et de Botanique Appliquée), 273-293.

Faerber, J. (2000) De l'incendie destructeur à une gestion raisonnée de l'environnement: le rôle du feu dans les dynamiques paysagères dans les Pyrénées centrales françaises. Sud-Ouest Européen 7, 69-80.

Galop, D., Vanniere, B. and Fontugne, M. (2002) Human activities and fire history since $4500 \mathrm{BC}$ on the northern slope of the Pyrenees: a record from Cuguron (central Pyrenees, France). In: Thiébault, S. (ed.) Charcoal Analysis. Methodological Approaches, Palaeoecological Results and Wood Uses. Proceedings of 
II Intern. Meeting of Anthracology, Paris, 2000. BAR International Series 1063, 43-51.

Gomez, D. and Fillat, F. (1984) Utilisation du frêne comme arbre fourrager dans les Pyrénées de Huesca. In: Lazare, J.J., Marty, R. and Dajoz, R. (eds) Ecologie et biogéographie des milieux montagnards et de haute altitude. Documents d'Écologie Pyrénéenne III-IV, 481-489.

Grove, A.T. and Rackham, O. (2001) The Nature of Mediterranean Europe. An Ecological History. Yale University Press, New Haven, p. 384.

Lambert, B. and Parmain, V. (1990) Les brûlages dirigés dans les Pyrénées-Orientale. De la régénération des pâturages d'altitude à la protection des forêts. Revue Forestière Française, T.42, pp. 140-155.

Lapparent, H. de (1890) Voyage d'étude dans les hauts pâturages de la chaîne des Pyrénées. L'Avenir, lournal de l'Ariège, 27 April to 11 September 1890.

Lefebvre, Th. (1933) Les Modes de Vie dans Jes Pyrénées Atlantiques Orientales. Colin, Paris.

Métailié, J.P. (1981) Le Feu Pastoral dans les Pyrénées Centrales. Toulouse, CNRS Editions.

Métailié, J.P. (1986) Les chênaies des montagnes pyrénéo-cantabriques, un élément forestier du système agropastoral. Revue Géog Pyrénées Sud-Ouest, 57(3), 313-324.

Métailié, J.P. (1996) La forêt du village et la forêt charbonnée. La mise en place des paysages forestiers dans la chaîne pyrénéenne. In: Cavaciocchi, S. (ed.) L'uomo e la foresta, secc. XIII-XVIII. Istituto Datini, Atti della $20^{\circ}$ settimana di studi, Prato, 8-13 mai 1995. Le Monnier, Florence, pp. 397-422.

Métailié, J.P. (1998) Le savoir-brûler dans les Pyrénées. De "l'écobuage" au "brûlage dirigé", la transformation d'une pratique traditionnelle en outil de gestion de l'espace. In: Rousselle, A. (ed.) Monde Rural et Histoire des Sciences en Méditerranée. Du bons sens à la logique. CRHISM, PUP, pp. 165-179.

Métailié, \}.P. and Faerber, J. (2003). Quinze années de gestion des feux pastoraux dans les Pyrénées: du blocage à la concertation. Sud-Ouest Européen 16, 37-52.

Métailié, J.P. and Paegelow, M. (2004) Land abandonment and the spreading of the forest in the Eastern French Pyrénées in the 19th to 20th centuries. In: Mazzoleni, 5. et al. (eds) Recent Dynamics of the Mediterranean Vegetation and Landscape. John Wiley \& Sons, Chichester, UK, pp. 219-236.

Moreno, D. and Poggi, G. (1996) Storia delle risorse boschive nelle montagne mediterranee: modeli di interpretazione per le produzioni foraggiere in regime consuetudinario. In: Cavaciocchi, S. (ed.) L'uomo e la Foresta, secC. XIII-XVIII. Istituto Datini, Atti della $20^{\circ}$ settimana di studi, Prato, 8-13 mai 1995. Le Monnier, Florence, pp. 635-653.

Moreno, D. and Poggi, G. (1998) Identification des pratiques agro-sylvo-pastorales et des savoirs naturalistes locaux : mise à contribution de l'écologie historique des sites. In: A. Rousselle (ed.) Monde Rural et Histoire des Sciences en Méditerranée. Du bons sens à la logique. Centre de Recherches Historiques sur les Sociétés Mériodionales, Presses Universitaires de Perpignon, PUP, pp. 151-163.

Moreno, D. and Raggio, O. (1990) The making and fall of an intensive pastoral land use system in the eastern Liguria (XVI-XIXth c.). In: Maggi, R., Nisbet, R. and Barker, G. (eds) The Archeology of Pastoralism in Southern Europe. Rivista di studi liguri, LVI, 1990, pp. 193-217.

PASTUM (1998) Numéro spécial "Brûlages dirigés". AFP, 51-52, 120.

Rackham, O. (1996) Forest history of countries without much forest: questions of conservation and savanna. In: Cavaciocchi, S. (ed.) L'uomo e la Foresta, secc. XIII-XVIII. Istituto Datini, Atti della $20^{\circ}$ settimana di studi, Prato, 8-13 mai 1995. Le Monnier, Florence, pp. 297-326.

Ribet, N. (1996) Le feu pastoral dans le Parc Naturel des Volcans d'Auvergne. Revue d'Auvergne, 539, 103-119.

Sigaut, F. (1987) L'arbre fourrager en Europe: rôle et évolution des techniques. In: La Forêt et l'Elevage en Région Méditerranéenne Française. Fourrages, no. hors série, 45-54.

SUAIA Pyrénées (2002) Les exploitations pastorales pyrénéennes, entre résistance et dynamisme. Agreste, Données no. 9, p. 4.

Vannière, B., Galop, D., Rendu, Ch. and Davasse, B. (2001) Feu et pratiques agro-pastorales dans les Pyrénées-Orientales: le cas de la montagne d'Enveitg (Cerdagne, Pyrénées-Orientales, France). Sud-Ouest Européen 11, 29-42. 